\title{
Update in the Management of Penile Cancer
}

\author{
Jorge R. Caso, Alejandro R. Rodriguez, Jose Correa, Philippe E. Spiess \\ Division of Genitourinary Oncology Program, H. Lee Moffitt Cancer Center and Research Institute, \\ Tampa, Florida, USA
}

\begin{abstract}
Purpose: The management of penile cancer has evolved as less invasive techniques are applied in the treatment of the primary tumor and inguinal lymph nodes.

Materials and Methods: Herein we review the literature focusing on advances in the preservation of the phallus as well as less morbid procedures to evaluate and treat the groins.

Results: Promising imaging modalities for staging are discussed. New techniques are described and tables provided for penile preservation. We also review the contemporary morbidity of modified surgical forms for evaluation of the inguinal nodes.

Conclusions: Advances in surgical technique have made phallic preservation possible in a greater number of primary penile cancers. The groins can be evaluated for metastasis with greater accuracy through new radiologic means as well as with less morbid modified surgical techniques.
\end{abstract}

Key words: penile cancer; staging; treatment; lymphadenectomy

Int Braz J Urol. 2009; 35: 406-15

\section{INTRODUCTION}

In the United States squamous cell carcinoma of the penis is a rarely diagnosed malignancy with an incidence of 0.58 cases per 100,000 (1). This rate has been in gradual decline over the last thirty years (1). In developing countries, the incidence is more considerable, due in part to cultural and hygienic differences $(2,3)$. Several etiologic risk factors have been recognized in the development of this malignancy. Exposure to the human papillomavirus, lack of neonatal circumcision (especially when associated with phimosis), and exposure to tobacco, among other causes, have been implicated (2-5).

In this article, we review the current management of penile carcinoma. An overview of newer phallic preservation techniques, as well as the staging of the inguinal nodes with minimally invasive and non-invasive methods, will be provided.

\section{STAGING}

Staging is usually accomplished via the 1987 TNM classification, most recently released in 2002 (6). It has been criticized for prognostic inadequacies as well as for the difficulty of properly assessing clinical stage using only the physical exam and imaging (7). Indeed, some authors choose to report contemporary series according to the 1978 classification $(8,9)$, due in part to a belief that therapy should be determined only by the prior assignment of a clinical stage $(10,11)$. 
With regards to the primary tumor, the initial assessment should be made by physical examination. It has been shown that in experienced hands, its correlation with the histopathologic examination after surgery is superior to that which can be derived from magnetic resonance imaging (MRI) or ultrasound (US) (12). These modalities would be reserved for lesions in which an adequate exam could not be performed, such as in the morbidly obese patient. However, the use of an intracavernosal injection of prostaglandin E1 as an adjunct prior to MRI scan has shown promise in some series by improving its accuracy in assessing the clinical stage of the primary tumor $(13,14)$. The sensitivities and specificities, respectively, for this modality in correctly assessing clinical T1 tumors are $85 \%$ and $83 \%$, for T2 tumors $75 \%$ and $89 \%$, and for T3 tumors $88 \%$ and $98 \%$ (14). Additionally, a biopsy of the lesion is necessary to confirm the diagnosis. The clinician must be wary, however, as prognostic pathological clues are not always apparent on superficial biopsy, and the grade and stage may differ from that of the final specimen (15). This latter point is especially important as penile conservation therapies become increasingly promoted, thereby eliminating the chance for more complete pathologic review from an amputation specimen.

Equally problematic is the staging of nodal disease. Here again, the initial assessment is made by physical examination, through palpation of the bilateral inguinal region. If the nodes are non-palpable after an adequate physical exam, there is generally no indication for imaging (16). However, new technologies such as lymphotropic nanoparticle enhanced MRI may enhance or replace the palpated findings. In a series of seven patients a total of 113 lymph nodes were evaluated and 13 found to be malignant on node dissection. The calculated sensitivity was $100 \%$ and negative predictive value also $100 \%$ (17). A specificity of $97 \%$ and positive predictive value of $81 \%$ was attributed to false positives secondary to fibrotic nodes (17). This technique not only indicated for which patients should undergo lymphadenectomy, but also specified laterality. High-resolution transducer US, which relies on several morphologic characteristics of malignant nodes (such as shape, echogenicity, and internal structures, among others) may also have a role in identifying patients with metastases (18). These methods should be differentiated from traditional computed axial tomography (CT), MRI, and US imaging, which use size criteria to identify suspicious nodes and are therefore associated with a higher rate of false positives.

When the nodes are palpable, management usually consists of 4-6 weeks of antibiotics commencing after the primary lesion has been treated (19). Almost half of suspicious lymph nodes palpated during the initial presentation are enlarged due to inflammatory changes; however, those that become palpable during later surveillance are malignant in 70 to $100 \%$ of cases $(16,20)$. If the inguinal lymph nodes are positive for cancer, evaluation of the pelvic nodes should be carried out with a CT (16) or MRI. The imaging field may be extended to the abdomen if disease is present in the pelvis, and all patients with node positive disease should also undergo a chest $\mathrm{X}$-ray (16). A chest X-ray may also be considered in all newly diagnosed patients, with chest CT followup for suspicious findings. Although not standard, positron emission tomography alone or in conjunction with CT has shown promise in detecting metastatic lesions $(21,22)$. In one study of thirteen patients, five of whom had histopathologically proven lymph node metastasis, 15 of 16 lymph nodes were identified as true positives, while 1 of 9 lymph nodes was a false negative (22).

\section{SURGERY OF THE PRIMARY TUMOR}

The obvious psychological toll associated with genital disfigurement has prompted the development of organ sparing techniques. Carcinoma in situ has been successfully treated with photodynamic therapy (PDT) and topical agents. In the largest reported series of PDT ten patients-three of which had bowenoid papulosis- received therapy with an average of 4.5 treatments in those who were completely cleared (23). 5-fluorouracil and more recently the immune response modifier imiquimod $5 \%$ cream have been used with biopsy proven eradication of the lesion (24-26). Cryosurgery with liquid nitrogen has been reported in superficial, low grade tumors (27).

Mohs microsurgery has had good results in tumors that are not excessively large, deeply invasive, 
or involving the urethral meatus (28). Radiation, both by brachytherapy and external beam radiotherapy, preserves function and establishes cancer control in select patients (29-31). Phallic preservation is possible in over half to three-quarters of those treated in this manner. It is likely best utilized in tumors smaller than $4 \mathrm{~cm}$ with less than $1 \mathrm{~cm}$ of invasion (29). Neodymium: yttrium-aluminum-garnet (Nd: Yag) and $\mathrm{CO} 2$ lasers have been used primarily in early stage penile cancers, and may be particularly effective for carcinoma in situ or for $\mathrm{T} 1$ and $\mathrm{T} 2$ lesions that are 3 $\mathrm{cm}$ or smaller (8,32-34). Some no longer apply this technology to T2 tumors as there may be a higher risk for nodal metastasis (35). Neoadjuvant reductive chemotherapy using vincristine, bleomycin and methotrexate with peniscopy in concert with $\mathrm{CO} 2$ laser has been reported with favorable results (36).

In a recent large, retrospective multi-institutional series laser therapy, local excision, and radiotherapy were compared to partial or total penectomy. Local recurrence rates were higher with penile preservation compared to partial or total amputation $(27.7 \%$ versus $5.3 \%$ ) (34). Five year disease specific survival in those who locally recurred was $92 \%$, however, prompting the authors to conclude that there is little impact on survival from utilizing phallic preservation techniques (34).

Modified surgical methods that avoid total or traditional partial penile amputations and remove minimal tissue are also being employed for select tumors. Glans resurfacing has been performed for carcinoma in situ and involves removing all superficial glans and coronal tissue down to the corpus spongiosum. A partial thickness skin graft is then harvested to cover the defect $(37,38)$. "Conservative surgical techniques" consisting of completely removing a tumor guided by preoperative mapping and with frozen section examination of margins preserve uninvolved structures (39). With extended follow-up, the results have been promising (39). Glansectomy has been reported with no local recurrences in select cases $(38,40,41)$. Others have performed partial glansectomy and partial penectomy with reconstruction of the glans $(38,41,42)$. For results of select studies, please see Table-1.

For grade 3 and deeply invasive tumors, particularly those not on the prepuce or glans, partial or total penectomy is the standard therapy (16). Classic teaching holds that the primary penile tumor should be excised with a $2 \mathrm{~cm}$ margin (19); however, this has more recently been called into question. In a prospective study grade 1 and 2 tumors were found histologically to extend less than $1 \mathrm{~cm}$ and grade 3 tumors less than $1.5 \mathrm{~cm}$ from the gross margin (43). It would therefore appear that the limits of resection should be based on the grade of the tumor as determined on biopsy. This has implications for conservative surgery, and indeed in one study where organ sparing techniques were used histopathologic margins were within $1 \mathrm{~cm}$ in about half and less than $2 \mathrm{~cm}$ in $90 \%$ of the resection specimens (44). In light of these findings, some authors have advocated removing a $1 \mathrm{~cm}$ margin from the "palpable" (as opposed to the visible) edge of the tumor (45). Only one patient out of thirty-nine experienced a recurrence using this limit (45).

Partial penectomies should leave a $2.5-3 \mathrm{~cm}$ penile stump for minimal functionality (19). Large or advanced stage lesions, particularly those at the base of the penis, may be best treated by total penectomy with perineal urethrostomy (19).

\section{ASSESSMENT OF THE INGUINAL NODES}

Close to $25 \%$ of patients with non-palpable lymph nodes on presentation harbor metastatic disease (46). The staging modalities previously mentioned offer hope that this subgroup may be identified in a non-invasive manner in the near future. Identifying patients with occult metastases is important because it has been shown that immediate lymphadenectomy confers a survival advantage over surgery deferred until palpable disease develops $(47,48)$. In a recent series of forty patients, the 3-year disease-specific survival of patients with metastatic nodes detected on surveillance was $35 \%$ versus $84 \%$ in those who underwent early resection (48). These numbers are very similar to those that have been reported with more extensive (6-7 year) follow-up (47).

Several risk factors for nodal metastases have been identified, and may be used to direct surgical intercession. A direct correlation between tumor grade and the likelihood of the inguinal metastases was first 
Table 1 - Results of select contemporary penis conservation therapies.

\begin{tabular}{|c|c|c|c|c|c|c|}
\hline Study & Year & \# Pts & Stage & Technique & $\begin{array}{c}\text { Local } \\
\text { Recurrence }\end{array}$ & $\begin{array}{l}\text { Follow-up } \\
\text { in Months }\end{array}$ \\
\hline Van Bezooijen (32) & 2001 & 19 & Tis & Laser (Nd:YAG, CO2) & $26 \%$ & Mn $32(1-95)$ \\
\hline Windhal (33) & 2003 & 67 & Tis-T2 & Laser (Nd:YAG, CO2) & $19 \%$ & $\operatorname{Md} 42(12-186)$ \\
\hline Lont (8) & 2005 & 104 & $\mathrm{~T} 1, \mathrm{~T} 2$ & $\begin{array}{c}\text { Excision, Laser (Nd:YAG, } \\
\text { CO2) }\end{array}$ & $37.50 \%$ & Md $106(16-543)^{1}$ \\
\hline Meijer (35) & 2007 & 44 & Tis-T2 & Excision, Laser (Nd:YAG) & $48 \%$ & Mn $53.2(+/-43.3)$ \\
\hline Bandieramonte (36) & 2008 & 224 & Tis-T1 & $\begin{array}{c}\text { Excision, Laser (CO2), } \\
\text { Chemotherapy }\end{array}$ & $17.5 \%$ & $\operatorname{Md} 66(35-132)^{2}$ \\
\hline Leijte (34) & 2008 & $\begin{array}{c}289 \\
105 \\
21 \\
21\end{array}$ & Tis-T2 & $\begin{array}{c}\text { Laser (Nd:YAG, CO2) } \\
\text { Local excision } \\
\text { Radiation therapy } \\
\text { External RT }\end{array}$ & $27.7 \%$ & Md $60.6(3-358)^{1}$ \\
\hline Ozsahin (31) & 2006 & $\begin{array}{l}7 \\
1\end{array}$ & $\mathrm{~T} 1-\mathrm{T} 3$ & $\begin{array}{c}\text { External RT, brachytherapy } \\
\text { Brachytherapy }\end{array}$ & $61 \%^{3}$ & Md $62(6-454)$ \\
\hline Minstry (30) & 2007 & 17 & TX, Tis-T3 & External RT & $37 \%$ & NA \\
\hline Crook (29) & 2008 & 67 & $\mathrm{TX}$, Tis-T3 & Brachytherapy & $13 \%$ & $\operatorname{Md} 48$ (4-194) \\
\hline Shindel (28) & 2007 & 33 & Tis-T3 & Mohs micrographic surgery & $32 \%$ & Md 37 (0.5-214) \\
\hline Bissada (39) & 2003 & 30 & NS & $\begin{array}{c}\text { Conservative surgical } \\
\text { excision }\end{array}$ & $8 \%$ & $12-360$ \\
\hline Pietrzak (41) & 2004 & 39 & Ta-T3 & $\begin{array}{l}\text { Partial GS up to partial } \\
\text { penectomy }\end{array}$ & $3 \%$ & Mn 16 \\
\hline McDougal (42) & 2005 & $\begin{array}{l}5 \\
2\end{array}$ & $\mathrm{~T} 1, \mathrm{~T} 2$ & $\begin{array}{c}\text { Partial GS } \\
\text { Excision of shaft skin }\end{array}$ & $13 \%$ & $12-60$ \\
\hline Hadway (37) & 2006 & 8 & Tis & Glans resurfacing & $0 \%$ & Md $30(7-45)$ \\
\hline Palminteri (38) & 2007 & $\begin{array}{c}1 \\
11\end{array}$ & $\begin{array}{r}\text { Tis } \\
\mathrm{T} 1, \mathrm{~T} 2\end{array}$ & $\begin{array}{c}\text { Glans resurfacing } \\
\text { GS up to partial penectomy }\end{array}$ & $0 \%$ & Mn $32(12-60)$ \\
\hline
\end{tabular}

\# = number; Pts = patients; $N A=$ not available; $R T=$ radiation therapy; $G S=$ glansectomy; $M n=$ mean; $M d=$ median

1 includes patients treated by other means; 2 interquartile range; 3 includes 4 patients who had excisional biopsy but refused definitive radiotherapy.

established (49). In one study in which prophylactic lymphadenectomies were performed, clinically negative groins with grade 1 or 2 tumors with no or minimal invasion were cancer free whereas tumors, which invaded the corpora or were poorly differentiated had microscopic cancer in $78 \%$ of the removed lymph nodes (50). In a subsequent study tumor stage, vascular invasion, and a proportion of greater than
$50 \%$ poorly differentiated cancer were shown to be independent prognostic factors for lymph node metastasis (46). More recently a nomogram has been developed which incorporates stage, grade, tumor thickness, histologic growth pattern, vascular/lymphatic embolization, and clinical node status in order to calculate the probability of the inguinal area being pathologically positive (51). 
A less morbid approach to early, complete inguinal lymphadenectomy involves staging the groins by first sampling the sentinel lymph node or nodes. This was first performed in a static, anatomical fashion with favorable results (52) which were unfortunately not duplicated in later series (53). The technique is no longer recommended (16,53). Instead dynamic sentinel node biopsy (DSNB) has been adopted. Although there is variability between surgical groups in the exact technique, usually some time prior to the scheduled surgery a radiotracer is injected into the remnant portion of the penis closest to where the primary tumor had been resected. On the day of surgery, dye may also be injected. The sentinel lymph node(s) is thus located visually and with a probe. This has been accomplished via an open technique through skin flaps (54) or by first marking the overlying skin after detection of radioactivity (55-57). A criticism of DSNB is that the false negative rate is a relatively high $15-16 \%(56,58)$ with a consequently low sensitivity that has deemed the technique insufficient by some researchers (54). This remains true in cases where the nodes are palpable (59).

Alternatively high resolution US with fine needle aspiration of suspicious nodes may be used to identify occult metastasis and those patients who require complete lymphadenectomy. Criteria for suspicious nodes include a length to width ratio less than 2 , a concentrically or eccentrically wide cortex, and a narrow to absent hilum (60). Compared to DSNB, at median follow-up of 18 months the sensitivity per groin was only $39 \%$ with a specificity of $100 \%(60)$. The authors concluded that the technique is useful in screening patients and avoiding DSNB when the aspirate is positive for cancer (60). These two modalities were used in a complementary fashion in a more recent paper. Sonographic criteria included increased size, abnormal shape, absence of echogenicity in the hilum, hypoechogenicity of the node, necrosis, and abnormal vascularity (57). At a median follow up of 11 months the respective sensitivity and specificity for US compared to DSNB were 74 and $77 \%$; interestingly, US identified two patients with metastasis who were originally considered negative by DSNB (57).

Modification of the traditional inguinal lymph node dissection, popularized through the work of Catalona, is used to decrease the morbidity of inguinal lymphadenectomy $(61,62)$. If cancer cells are found, a full template dissection is completed. Catalona's modified boundary preserves the saphenous vein as well as the subcutaneous tissue superficial to Scarpa's fascia; in addition fewer nodes are removed and the incision is shorter (62). The surgical boundaries are the external oblique aponeurosis and spermatic cord (superior), the fascia lata distal to the fossa ovalis (inferior), the adductor longus (medial) and the femoral artery (lateral) (62). A locoregional recurrence rate of $15 \%$ (2/13 patients) was reported in a prospective study utilizing this template (63), similar to a more recent retrospective study where one out of eleven patients $(9 \%)$ had an out of field recurrence at the base of the penis (64). Slightly different boundaries were proposed by Costa et al. setting the limits at the adductor longus (medial), the medial surface of the femoral and saphenous veins (lateral), and the inguinal arcade (superior), forming a triangle $(65,66)$. With a mean follow-up greater than six years the reported loco-regional recurrence rate was $5.5 \%$ of negative groins (or 2 out of 18 , or $11 \%$ of patients) (65). The possibility of leaving disease behind has dampened enthusiasm for the modified procedures. An interesting study has recently been reported whereby hybrid single-photon emission CT lymphatic drainage patterns were analyzed in a cohort of patients. In $10 \%$, the sentinel nodes were located in the lateral superior zone (based on Daseler's classification) which is not sampled with either modified dissection, providing a rationale for recurrences (67).

Removing all superficial inguinal lymph node tissue for diagnosis provides a more complete assessment for staging, but has traditionally been associated with high morbidity $(68,69)$. However, certain modifications have been introduced to lessen the chances of a severe complication. Many of the issues that arise are wound related complications; the use of a Gibson incision has been advocated by some authors to reduce them (10). Minimally invasive means of performing inguinal lymphadenectomy, via straight laparoscopy or with robotic assistance, have practically eliminated cutaneous complications (70-74). Prophylactic antibiotics, the appropriate use of drains, early ambulation, and modifications in surgical technique, among others, encompass some of the changes that have been applied with success in minimizing morbidity $(68,69)$. 


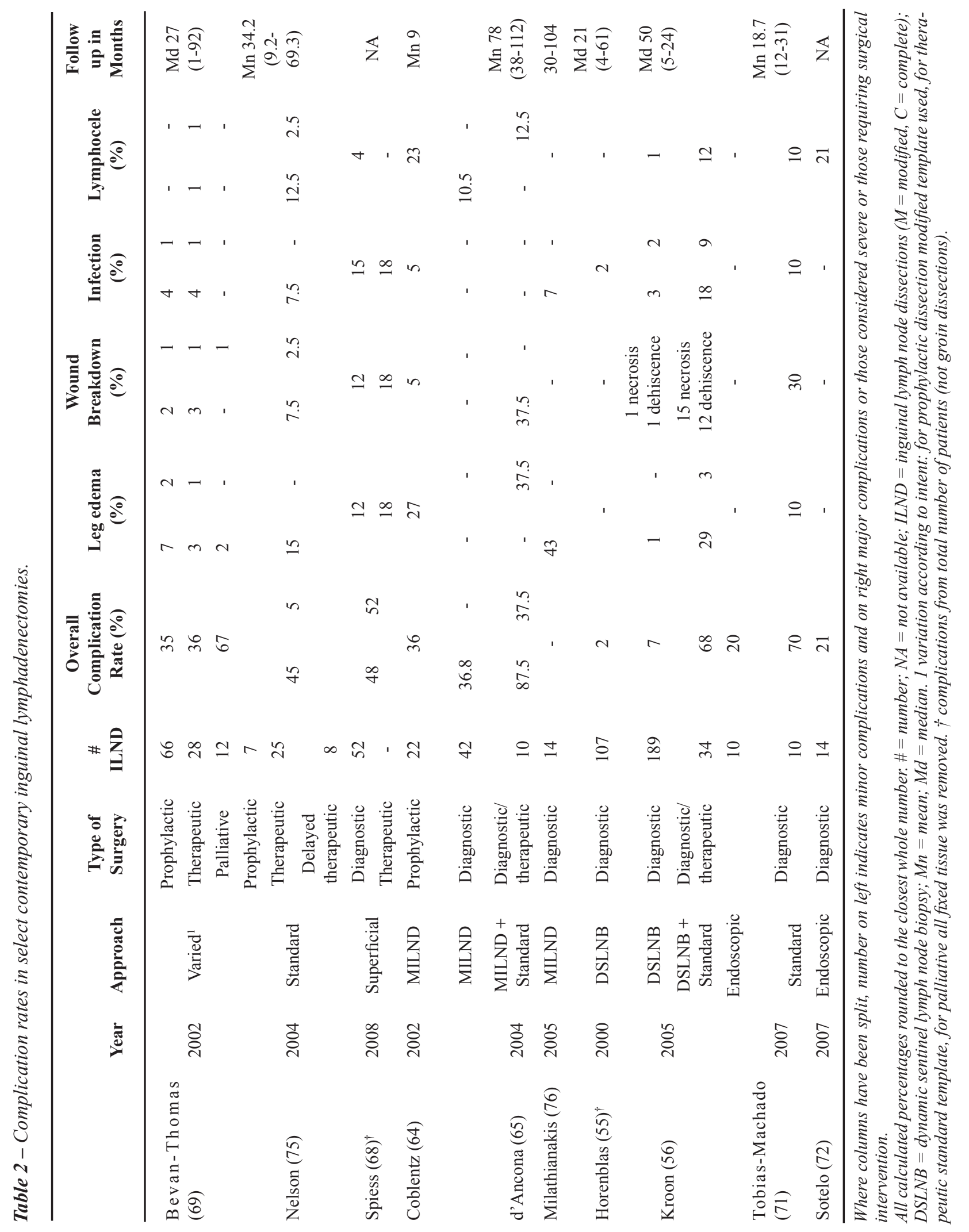


For a review of complication rates for recent series of modified, standard, and endoscopic inguinal lymph node dissections, please refer to Table-2.

\section{CONCLUSIONS}

Penile cancer is a rare disease, which has been studied through relatively small case series from large academic centers. Recently, several paradigms have been altered in the management of this cancer. The drive for decreased morbidity with continued cancer control has lead to penile preservation surgery, better staging modalities, and minimally invasive techniques for the exploration of the inguinal nodes. It is hoped these techniques prove to have equivalent or better oncologic outcomes in order to lessen the morbidity associated with the surgical therapy of this disease.

\section{CONFLICT OF INTEREST}

None declared.

\section{REFERENCES}

1. Barnholtz-Sloan JS, Maldonado JL, Pow-sang J, Giuliano AR: Incidence trends in primary malignant penile cancer. Urol Oncol. 2007; 25: 361-7. Erratum in: Urol Oncol. 2008; 26: 112. Guiliano, Anna R [corrected to Giuliano, Anna R].

2. Misra S, Chaturvedi A, Misra NC: Penile carcinoma: a challenge for the developing world. Lancet Oncol. 2004; 5: 240-7.

3. Favorito LA, Nardi AC, Ronalsa M, Zequi SC, Sampaio FJ, Glina S: Epidemiologic study on penile cancer in Brazil. Int Braz J Urol. 2008; 34: 587-91; discussion 591-3.

4. Daling JR, Madeleine MM, Johnson LG, Schwartz SM, Shera KA, Wurscher MA, et al.: Penile cancer: importance of circumcision, human papillomavirus and smoking in in situ and invasive disease. Int $\mathrm{J}$ Cancer. 2005; 116: 606-16.

5. Tsen HF, Morgenstern H, Mack T, Peters RK: Risk factors for penile cancer: results of a population-based case-control study in Los Angeles County (United States). Cancer Causes Control. 2001; 12: 267-77.
6. Greene FL, Fritz AG, Balch CM, Haller DG, Page DL, Fleming ID, et al.: AJCC Cancer Staging Handbook. 6th ed. New York City, Springer-Verlag. 2002.

7. Leijte JA, Gallee M, Antonini N, Horenblas S: Evaluation of current TNM classification of penile carcinoma. J Urol. 2008; 180: 933-8; discussion 938.

8. Lont AP, Gallee MP, Meinhardt W, van Tinteren H, Horenblas S: Penis conserving treatment for T1 and T2 penile carcinoma: clinical implications of a local recurrence. J Urol. 2006; 176: 575-80; discussion 580.

9. Ornellas AA, Kinchin EW, Nóbrega BL, Wisnescky A, Koifman N, Quirino R: Surgical treatment of invasive squamous cell carcinoma of the penis: Brazilian National Cancer Institute long-term experience. J Surg Oncol. 2008; 97: 487-95.

10. Ornellas AA: Management of penile cancer. J Surg Oncol. 2008; 97: 199-200.

11. Horenblas S, van Tinteren H: Squamous cell carcinoma of the penis. IV. Prognostic factors of survival: analysis of tumor, nodes and metastasis classification system. J Urol. 1994; 151: 1239-43.

12. Lont AP, Besnard AP, Gallee MP, van Tinteren H, Horenblas S: A comparison of physical examination and imaging in determining the extent of primary penile carcinoma. BJU Int. 2003; 91: 493-5.

13. Scardino E, Villa G, Bonomo G, Matei DV, Verweij F, Rocco B, et al.: Magnetic resonance imaging combined with artificial erection for local staging of penile cancer. Urology. 2004; 63: 1158-62.

14. Kayes O, Minhas S, Allen C, Hare C, Freeman A, Ralph D: The role of magnetic resonance imaging in the local staging of penile cancer. Eur Urol. 2007; 51: 1313-8; discussion 1318-9.

15. Velazquez EF, Barreto JE, Rodriguez I, Piris A, Cubilla AL: Limitations in the interpretation of biopsies in patients with penile squamous cell carcinoma. Int $\mathrm{J}$ Surg Pathol. 2004; 12: 139-46.

16. Solsona E, Algaba F, Horenblas S, Pizzocaro G, Windahl T; European Association of Urology: EAU Guidelines on Penile Cancer. Eur Urol. 2004; 46: 1-8.

17. Tabatabaei S, Harisinghani M, McDougal WS: Regional lymph node staging using lymphotropic nanoparticle enhanced magnetic resonance imaging with ferumoxtran-10 in patients with penile cancer. J Urol. 2005; 174: 923-7; discussion 927.

18. Esen G: Ultrasound of superficial lymph nodes. Eur J Radiol. 2006; 58: 345-59.

19. Pow-Sang MR, Benavente V, Pow-Sang JE, Morante C, Meza L, Baker M, Pow-Sang JM: Cancer of the penis. Cancer Control. 2002; 9: 305-14. 
20. Ornellas AA, Seixas AL, Marota A, Wisnescky A, Campos F, de Moraes JR: Surgical treatment of invasive squamous cell carcinoma of the penis: retrospective analysis of 350 cases. J Urol. 1994; 151: 1244-9.

21. Ravizzini GC, Wagner M, Borges-Neto S: Positron emission tomography detection of metastatic penile squamous cell carcinoma. J Urol. 2001; 165: 16334.

22. Scher B, Seitz M, Reiser M, Hungerhuber E, Hahn $\mathrm{K}$, Tiling R, et al.: 18F-FDG PET/CT for staging of penile cancer. J Nucl Med. 2005; 46: 1460-5.

23. Paoli J, Ternesten Bratel A, Löwhagen GB, Stenquist $\mathrm{B}$, Forslund $\mathrm{O}$, Wennberg AM: Penile intraepithelial neoplasia: results of photodynamic therapy. Acta Derm Venereol. 2006; 86: 418-21.

24. Schroeder TL, Sengelmann RD: Squamous cell carcinoma in situ of the penis successfully treated with imiquimod 5\% cream. J Am Acad Dermatol. 2002; 46: 545-8.

25. Taliaferro SJ, Cohen GF: Bowen's disease of the penis treated with topical imiquimod 5\% cream. J Drugs Dermatol. 2008; 7: 483-5.

26. Cook-Bolden F, Weinberg JM: Topical imiquimod $5 \%$ cream in the treatment of Bowen's disease of the penis. J Am Acad Dermatol. 2002; 46: 146-7.

27. Michelman FA, Filho AC, Moraes AM: Verrucous carcinoma of the penis treated with cryosurgery. J Urol. 2002; 168: 1096-7.

28. Shindel AW, Mann MW, Lev RY, Sengelmann R, Petersen J, Hruza GJ, et al.: Mohs micrographic surgery for penile cancer: management and long-term followup. J Urol. 2007; 178: 1980-5.

29. Crook J, Ma C, Grimard L: Radiation therapy in the management of the primary penile tumor: an update. World J Urol. 2008; 18. [Epub ahead of print]

30. Mistry T, Jones RW, Dannatt E, Prasad KK, Stockdale $\mathrm{AD}$ : A 10-year retrospective audit of penile cancer management in the UK. BJU Int. 2007; 100: 1277-81.

31. Ozsahin M, Jichlinski P, Weber DC, Azria D, Zimmermann M, Guillou L, et al.: Treatment of penile carcinoma: to cut or not to cut? Int J Radiat Oncol Biol Phys. 2006; 66: 674-9.

32. van Bezooijen BP, Horenblas S, Meinhardt W, Newling DW: Laser therapy for carcinoma in situ of the penis. J Urol. 2001; 166: 1670-1.

33. Windahl T, Andersson SO: Combined laser treatment for penile carcinoma: results after long-term followup. J Urol. 2003; 169: 2118-21.

34. Leijte JA, Kirrander P, Antonini N, Windahl T, Horenblas $\mathrm{S}$ : Recurrence patterns of squamous cell carcinoma of the penis: recommendations for follow-up based on a two-centre analysis of 700 patients. Eur Urol. 2008; 54: 161-8.

35. Meijer RP, Boon TA, van Venrooij GE, Wijburg CJ: Long-term follow-up after laser therapy for penile carcinoma. Urology. 2007; 69: 759-62.

36. Bandieramonte G, Colecchia M, Mariani L, Lo Vullo S, Pizzocaro G, Piva L, et al.: Peniscopically controlled $\mathrm{CO} 2$ laser excision for conservative treatment of in situ and T1 penile carcinoma: report on 224 patients. Eur Urol. 2008; 54: 875-82.

37. Hadway P, Corbishley CM, Watkin NA: Total glans resurfacing for premalignant lesions of the penis: initial outcome data. BJU Int. 2006; 98: 532-6.

38. Palminteri E, Berdondini E, Lazzeri M, Mirri F, Barbagli G: Resurfacing and reconstruction of the glans penis. Eur Urol. 2007; 52: 893-8.

39. Bissada NK, Yakout HH, Fahmy WE, Gayed MS, Touijer AK, Greene GF, et al.: Multi-institutional long-term experience with conservative surgery for invasive penile carcinoma. J Urol. 2003; 169: 500-2.

40. da Fonseca AG, Rabelo GN, Vidal KS, de Sousa FJ: Glandectomy with preservation of corpora cavernosa in the treatment of penile carcinoma. Int Braz J Urol. 2003; 29: 437-40.

41. Pietrzak P, Corbishley C, Watkin N: Organ-sparing surgery for invasive penile cancer: early follow-up data. BJU Int. 2004; 94: 1253-7.

42. McDougal WS: Phallic preserving surgery in patients with invasive squamous cell carcinoma of the penis. J Urol. 2005; 174: 2218-20, discussion 2220.

43. Agrawal A, Pai D, Ananthakrishnan N, Smile SR, Ratnakar C: The histological extent of the local spread of carcinoma of the penis and its therapeutic implications. BJU Int. 2000; 85: 299-301.

44. Minhas S, Kayes O, Hegarty P, Kumar P, Freeman A, Ralph D: What surgical resection margins are required to achieve oncological control in men with primary penile cancer? BJU Int. 2005; 96: 1040-3.

45. Korets R, Koppie TM, Snyder ME, Russo P: Partial penectomy for patients with squamous cell carcinoma of the penis: the Memorial Sloan-Kettering experience. Ann Surg Oncol. 2007; 14: 3614-9.

46. Slaton JW, Morgenstern N, Levy DA, Santos MW Jr, Tamboli P, Ro JY, et al.: Tumor stage, vascular invasion and the percentage of poorly differentiated cancer: independent prognosticators for inguinal lymph node metastasis in penile squamous cancer. J Urol. 2001; 165: 1138-42.

47. McDougal WS: Preemptive lymphadenectomy markedly improves survival in patients with cancer of the 
penis who harbor occult metastases. J Urol. 2005; 173 : 681.

48. Kroon BK, Horenblas S, Lont AP, Tanis PJ, Gallee MP, Nieweg OE: Patients with penile carcinoma benefit from immediate resection of clinically occult lymph node metastases. J Urol. 2005; 173: 816-9.

49. Horenblas S, van Tinteren H, Delemarre JF, Moonen LM, Lustig V, van Waardenburg EW: Squamous cell carcinoma of the penis. III. Treatment of regional lymph nodes. J Urol. 1993; 149: 492-7.

50. McDougal WS: Carcinoma of the penis: improved survival by early regional lymphadenectomy based on the histological grade and depth of invasion of the primary lesion. J Urol. 1995; 154: 1364-6.

51. Ficarra V, Zattoni F, Artibani W, Fandella A, Martignoni G, Novara G, et al.: Nomogram predictive of pathological inguinal lymph node involvement in patients with squamous cell carcinoma of the penis. $\mathrm{J}$ Urol. 2006; 175: 1700-4; discussion 1704-5.

52. Cabanas RM: An approach for the treatment of penile carcinoma. Cancer. 1977; 39: 456-66.

53. Pettaway CA, Pisters LL, Dinney CP, Jularbal F, Swanson DA, von Eschenbach AC, et al.: Sentinel lymph node dissection for penile carcinoma: the M. D. Anderson Cancer Center experience. J Urol. 1995; 154: 1999-2003.

54. Spiess PE, Izawa JI, Bassett R, Kedar D, Busby JE, Wong F, et al:: Preoperative lymphoscintigraphy and dynamic sentinel node biopsy for staging penile cancer: results with pathological correlation. J Urol. 2007; 177: 2157-61.

55. Horenblas S, Jansen L, Meinhardt W, Hoefnagel CA, de Jong D, Nieweg OE: Detection of occult metastasis in squamous cell carcinoma of the penis using a dynamic sentinel node procedure. J Urol. 2000; 163: $100-4$

56. Kroon BK, Lont AP, Valdés Olmos RA, Nieweg OE, Horenblas S: Morbidity of dynamic sentinel node biopsy in penile carcinoma. J Urol. 2005; 173: 813-5.

57. Crawshaw JW, Hadway P, Hoffland D, Bassingham S, Corbishley CM, Smith Y: Sentinel lymph node biopsy using dynamic lymphoscintigraphy combined with ultrasound-guided fine needle aspiration in penile carcinoma. Br J Radiol. 2009; 82: 41-8.

58. Kroon BK, Horenblas S, Meinhardt W, van der Poel HG, Bex A, van Tinteren H, et al.: Dynamic sentinel node biopsy in penile carcinoma: evaluation of 10 years experience. Eur Urol. 2005; 47: 601-6; discussion 606.

59. Heyns CF, Theron PD: Evaluation of dynamic sentinel lymph node biopsy in patients with squamous cell carcinoma of the penis and palpable inguinal nodes. BJU Int. 2008; 102: 305-9.

60. Kroon BK, Horenblas S, Deurloo EE, Nieweg OE, Teertstra HJ: Ultrasonography-guided fine-needle aspiration cytology before sentinel node biopsy in patients with penile carcinoma. BJU Int. 2005; 95: 517-21.

61. Catalona WJ: Modified inguinal lymphadenectomy for carcinoma of the penis with preservation of saphenous veins: technique and preliminary results. J Urol. 1988; 140: 306-10.

62. Colberg JW, Andriole GL, Catalona WJ: Long-term follow-up of men undergoing modified inguinal lymphadenectomy for carcinoma of the penis. Br $\mathrm{J}$ Urol. 1997; 79: 54-7.

63. Lopes A, Rossi BM, Fonseca FP, Morini S: Unreliability of modified inguinal lymphadenectomy for clinical staging of penile carcinoma. Cancer. 1996; 77: 2099-102.

64. Coblentz TR, Theodorescu D: Morbidity of modified prophylactic inguinal lymphadenectomy for squamous cell carcinoma of the penis. J Urol. 2002; 168: 13869.

65. d'Ancona CA, de Lucena RG, Querne FA, Martins MH, Denardi F, Netto NR Jr: Long-term followup of penile carcinoma treated with penectomy and bilateral modified inguinal lymphadenectomy. J Urol. 2004; 172: 498-501; discussion 501.

66. Costa RP, Schaal CH, Cortez JP: Nova proposta de linfadenectomia para cancer do penis: resultados preliminares. J Bras Urol. 1989; 15: 242-6.

67. Leijte JA, Valdés Olmos RA, Nieweg OE, Horenblas $\mathrm{S}$ : Anatomical mapping of lymphatic drainage in penile carcinoma with SPECT-CT: implications for the extent of inguinal lymph node dissection. Eur Urol. 2008; 54 : 885-90.

68. Spiess PE, Hernandez MS, Pettaway CA: Contemporary inguinal lymph node dissection: minimizing complications. World J Urol. 2008; 2. [Epub ahead of print]

69. Bevan-Thomas R, Slaton JW, Pettaway CA: Contemporary morbidity from lymphadenectomy for penile squamous cell carcinoma: the M.D. Anderson Cancer Center Experience. J Urol. 2002; 167: 1638-42.

70. Tobias-Machado M, Tavares A, Molina WR Jr, Forseto PH Jr, Juliano RV, Wroclawski ER: Video endoscopic inguinal lymphadenectomy (VEIL): minimally invasive resection of inguinal lymph nodes. Int Braz J Urol. 2006; 32: 316-21.

71. Tobias-Machado M, Tavares A, Ornellas AA, Molina WR Jr, Juliano RV, Wroclawski ER: Video endoscopic 
inguinal lymphadenectomy: a new minimally invasive procedure for radical management of inguinal nodes in patients with penile squamous cell carcinoma. J Urol. 2007; 177: 953-7; discussion 958.

72. Sotelo R, Sánchez-Salas R, Carmona O, Garcia A, Mariano M, Neiva G, et al.: Endoscopic lymphadenectomy for penile carcinoma. J Endourol. 2007; 21: 364-7; discussion 367.

73. Bishoff JA, Lackland AF, Basler JW, Teichman JM, Thompson IM: Endoscopy subcutaneous modified inguinal lymph node dissection (ESMIL) for squamous cell carcinoma of the penis. J Urol. 2003: 169; (Supl. 4): 78. Abstract 301.
74. Josephson DY, Jacobsohn KM, Link BA, Wilson TG: Robotic-assisted endoscopic inguinal lymphadenectomy. Urology. 2009; 73: 167-70; discussion 170-1.

75. Nelson BA, Cookson MS, Smith JA Jr, Chang SS: Complications of inguinal and pelvic lymphadenectomy for squamous cell carcinoma of the penis: a contemporary series. J Urol. 2004; 172: 494-7.

76. Milathianakis C, Bogdanos J, Karamanolakis D: Morbidity of prophylactic inguinal lymphadenectomy with saphenous vein preservation for squamous cell penile carcinoma. Int J Urol. 2005; 12: 776-8.

Accepted after revision: February 9, 2009

\section{Correspondence address:}

Dr. Philippe E. Spiess

Genitourinary Oncology Program

H. Lee Moffitt Cancer Center \& Research Institute 12902 Magnolia Drive

Tampa, Florida, 33612-9416, USA

Fax: + 1813 745-8494

E-mail: philippe.spiess@moffitt.org 